\title{
Investigating the Effect of Team-teaching Approach on ESP Students' English Proficiency; Evidence from Students' Attitudes
}

\author{
Mohammadhossein Besharati (Corresponding author) \\ Department of English Language and Literature, Yazd University, Yazd, Iran. \\ E-mail: mh.besharati@chmail.ir \\ Golnar Mazdayasna \\ Department of English Language and Literature, Yazd University, Yazd, Iran
}

Received: 28-01-2017

Published: 01-09-2017
Accepted: 17-04-2017

doi:10.7575/aiac.ijalel.v.6n.5p.41
Advance Access Published: July 2017

URL: http://dx.doi.org/10.7575/aiac.ijalel.v.6n.5p.41

\begin{abstract}
The current study was an attempt to investigate EFL students' attitudes regarding team-teaching approach. In addition, it explored to what extent the team-teaching approach was effective in terms of enhancing Electrical Engineering Students' English proficiency in an English for Specific Academic Purpose (ESAP) program. To this end, 60 university students studying Electrical Engineering at the faculty of Engineering in Yazd University enrolled in the ESP course participated in this study. Prior to the instruction, the students were randomly divided into two groups as control and experimental. The experimental group was instructed based on the team-teaching approach while the control group was taught based on the traditional approach. The data was gathered through a pretest, posttest, and a questionnaire. The analysis of data via independent sample t-test and descriptive analysis revealed that most of the students had a positive attitude toward utilizing team-teaching approach. Furthermore, the findings indicated that Electrical Engineering students who were taught through team teaching approach performed better than those taught by a single instructor.
\end{abstract}

Keywords: Team-teaching approach, Electrical Engineering Students, ESAP program, ESP approach

\section{Introduction}

No one can deny the fact that there has been a growing need to use English language in each specific professional field. In response to this need, the teaching of ESP has become a major concern in many countries. English for Specific Purposes (ESP) is defined as "a language course or program of instruction in which the content and aims of the course are fixed by the specific needs of a particular group of learners" (Richards \& Schmidt, 2010, p. 198). ESP provides the learners to use English in academic, professional or workplace settings.

The teaching of English for Academic Purposes (EAP) falls within the framework of what is generally called ESP, taking place in essence, and as its name suggests, in an educational environment. The reasons for its increasing relevance is due to the fact that English has changed from simply being another foreign language into having become a universal form of communication in all walks of life. Dudley-Evans and St. John (1998) state that the teaching process of any kind of language for occupational purposes should take as a starting pint the analysis of the four traditional skills within an appropriate context, that being, as far as possible, the conditions given in the workplace. Moreover, they subscribe to the idea that an effective syllabus must attempt to overcome the deficiencies of the educational system under which they are operating. EOP, therefore, encircles a reaction against the conventional humanistic approach wherein both teachers and students abide by the academic objective of knowing everything about the language being studied instead of concentrating attention on those skills most relevant within the workplace in the time allotted in the educational environment. (Dominguez \& Rokowski 2005) EOP can be defined as "the portion of the curriculum which prepares students for gainful employment in occupations ranging from low-skilled to sophisticated jobs in technical fields. (Anthony, 1997, p.56).EOP programs focus on developing communicative competence in a specific field, such as aviation, business, or tourism. EOP is more general compared to ESP because it does not focus on the specific job disciplines but it is more on general basic skills required by students in order to prepare students for the workforce. Examples of basic skills in EOP are reading, writing, listening and speaking. In countries where English is mainly utilized for academic purposes, like Iran, ESP has a definitive role. Furthermore, in Iran, after the Islamic revolution, in an effort to challenge westernization of the country and a strong trend to teach English language, ESP has developed and it forms a significant part of the curricula for many fields at universities. English for General Academic Purpose (EGAP) and English for Specific Academic Purpose (ESAP) are two branches of ESP. EGAP refers to the teaching of the features that are common to all disciplines (Long, 2005). However, ESAP is teaching of the features that distinguish one discipline from others (Ewer \& Lattore, 1969). Because of rapid expansion of ESP, ESAP courses became an 
important part of curricula for academic fields at universities (Atai, 2000). Furthermore, in Iran, English is the language of a lot of academic textbooks, especially in engineering and English language skills and knowledge of students who enter into the portals of engineering colleges differ considerably, it has become imperative to evaluate their capability to manage the syllabus of Communicative/Business English course prescribed for them. In the absence of adequate competency in English language skills, majority of the students find it difficult to become completely proficient in the technical terminologies of science and engineering textbooks written in English. Therefore, they require an adequate level of skills and knowledge in English in order to alleviate engineering learning and to keep step with the latest trends in the field of science and technology. When the language competency levels of the learners are assessed, it will become easier to design teaching methodologies appropriate for different groups. Regarding this fact, English for Specific Academic Purposes (ESP) came to being. In fact, there is an increasing need for ESAP programs in Iran. In fact, there is an increasing need for ESP programs around the world (Flowerdew, 1992). However, Iran is not an exception.

\subsection{Statement of the Problem}

Since English language skills and knowledge of students who enter into the portals of engineering colleges differ considerably, it has become imperative to evaluate their capability to manage the syllabus of Communicative/Business English course prescribed for them. In the absence of adequate competency in English language skills, majority of the students find it difficult to become completely proficient in the technical terminologies of science and engineering textbooks written in English. Therefore, they require an adequate level of skills and knowledge in English in order to alleviate engineering learning and to keep step with the latest trends in the field of science and technology. When the language competency levels of the learners are assessed, it will become easier to design teaching methodologies appropriate for different groups. Regarding this fact, English for Specific Academic Purposes (ESP) came to being. In fact, there is an increasing need for ESP programs around the world (Flowerdew, 1992). However, Iran is not an exception. English for General Academic Purpose (EGAP) and English for Specific Academic Purpose(ESAP) are two branches of ESP. EGAP refers to the teaching of the features that are common to all disciplines(Long, 2005). However, ESAP is teaching of the features that distinguish one discipline from others (Ewer \& Lattore, 1969). Because of rapid expansion of ESP, ESAP courses became an important part of curricula for academic fields at universities (Atai, 2000). In Iran, ESAP, as a branch of ESP, plays a fundamental role in curricula in all academic fields but teaching ESAP courses at Iranian universities seems unsatisfactory, also not conducive to learning the language. In most cases, it is similar to traditional approaches:

1. Lack of deep approaches to learning.

2. An emphasis on rote memorization.

3. Emphasis on transfer and assessment of factual knowledge rather than assessment of critical thinking.

In ESP/ESAP, all aspects of materials development should be designed based on learners' needs but most of the curriculum developers in Iran neglected needs analysis and trusted in their intuitions (Atai, 2002). Therefore, it is necessary to conduct a study in order to design materials to fulfill students' learning needs. The finding of the present study will shed light on most of the drawbacks and shortcomings and attempts to make changes in designing ESAP courses. To sum up, the result of this research will be useful for language teachers, content teachers, materials designers and administrators.

\subsection{The purpose of study}

The current study is an attempt to provide detailed description of designing an ESAP course for the students of Electrical Engineering at Yazd University, Iran.

\subsection{Research questions}

Efforts were made to find answers to the following questions.

1) What are the students' attitudes regarding team-teaching approach?

2) To what extent the team-teaching approach effective in terms of enhancing Electrical Engineering Students' English proficiency in an ESAP program?

\section{Review of Related Literature}

According to Tomlinson (2012, p. 144) materials development is both "a field of study and a practical undertaking". A field of study refers to the principles of language teaching, materials designing, materials implementation and evaluation. A practical undertaking refers to anything, which is done by teachers or learners in order to produce language input in a way, which maximizes learning. Singapore Wala, D. (2005) believes that developing materials for English language teaching is a difficult procedure. She suggests that course designers, language specialists or learners can provide feedback for materials developers. In addition, Hutchinson and Waters (1987) express different views on materials development. They believe that the teachers are the last resorts who can develop their own teaching materials if they do not find any way to use existing materials. On the other hand, Block (1991) believes that the teachers need to produce their own teaching materials. Similarly, Masuhara (2011) believes that materials development can help the teachers to be creative and effective in the classroom. Likewise, in Canniveng and Martinez's (2003) study on the evaluation of the general teacher education courses and regarding the data obtained from their research they claim that the materials development should be an indispensable component of both PRESET courses (the course held for the inexperienced native speakers and the non-native speakers who want to choose teaching as their professional career) 
and the INSET courses (the courses in which the experienced teachers who have taught for many years and want to update their knowledge participate). Tomlinson (2003) rightly points out that professional materials writers are responsible for developing commercial materials. These writers write the materials based on the analysis of the learners needs; however, the materials designed by them are not motivating enough for the students. Therefore, the qualification of materials writers has been a very important issue among the scholars. Dudly-Evans and St.John (1998, p.173) noted that "only a small proportion of good teachers are also good designers of course materials". Tomlinson (2003) believes that materials cannot be developed in isolation. In other words, effective materials can be developed when the specialists share their experiences of language learning and teaching with each other. Moreover, Bernard and Zemach (2003, p. 310)assert that good materials can be developed when a good and experienced teacher shares his experience with other teachers in the field and collaborates with them. According to Hutchinson and Waters (1987, p. 98), evaluation is a matter of judging the fitness of something for a particular purpose and is basically a matching process. They believe that materials evaluation may be an investment of money and time. Bernard and Zemach (2003, p. 314) identify evaluation as the critical step in the procedure of materials development. They consider teachers and learners, as sources when any newly developed materials have to be designed. It should be noted that it is easy to obtain data from teachers but gathering data from the learners is a challenging task. Therefore, they recommend using a questionnaire at the end of the course. Materials Evaluation is the last stage in ESP course design. Hutchinson and Waters (1987) mention that evaluation consists of two types: learner assessment and course evaluation. In fact, learner assessment must be done in order to determine whether and how much language instruction is needed. Hughes (1989) presents four purposes for materials evaluation: measuring the proficiency, diagnosing strengths and weaknesses of the newly developed materials, placing the learners in a course and finally, evaluation of their achievement in a course. ESP specialists should evaluate their programs to improve the program effectiveness. Therefore, course evaluation should be conducted to explore whether the objectives of the course are being achieved or not. Tomlinson (2003, p. 30) suggests a systematic evaluation and introduced three types of evaluation. The first type of evaluation is "pre-use", evaluation which aims to predict the effectiveness of the materials. The second type of evaluation is "whilst-use" evaluation, in which the materials are evaluated during the time they are used. It should be mentioned that it is more objective and reliable than pre-use evaluation. The last type of evaluation is, "post-use" evaluation, which aims at measuring the actual short-term and long-term effects of the materials. He mentions that this type of evaluation is the most reliable and valuable one however it is rarely used. Furthermore, Rubdy (2003, p. 40) notes that the effectiveness of the materials must be evaluated based on three categories:

1) Psychological validity of the materials, which is in accordance with the learners' needs.

2) Pedagogical validity of the materials, which is related to the teachers' skills, abilities and beliefs.

3) Process and content validity of the materials, which is relevant to the thinking underlying the materials writers' presentation of the content and approach to teaching and learning respectively.

Materials development in ESP courses is very crucial and it shows the effort and creativity of the course designers as well as the teachers. Riazi (2005) emphasizes on the importance of appropriate layout of the ESP materials. Authentic materials are the materials which are used in the real world are the best material that should be used in any English for Specific Academic Purposes (EAP) courses. This would give the learners a look on the real world that they will be entering once they have graduated. Materials can be considered as any source that can be used to help the learners in the procedure of language learning. They can be textbooks, workbooks, videos, photocopied handouts or anything that informs the language being learned (Tomlinson, 2010, p. 100). Three main factors are essential for designing ESP course materials, first of all is the criteria of modifying materials, the second one is subjective criteria on what teachers and students want from that material and last one is objective criteria, which is what the material really offers (Hutchinson \& Waters, 1987). There are at least two things to be elaborated about materials development. It is both a field of study and a practical undertaking. As a field of study, it studies the principles and procedures of the design, implementation, and evaluation of language teaching materials. As a practical undertaking, it involves the production, evaluation, and adaptation of language teaching materials, by teachers for their own classrooms and by materials writers for sale or distribution (Tomlinson, 2001). There are also several suggestions in the process of designing ESP materials. In fact, authors should consider types of skills to be developed as learners' goals. In addition, many materials writers in field of ESP are trying to make the materials interesting and motivating for the learners. In addition, Bernard and Zemach (2003, p. 313-314) introduce some criteria, which should be taken into account during designing ESP materials: First, the knowledge of the teachers who use ESP materials should be considered in all stages of the materials development. Another criterion is that developing ESP textbooks should be based on the guidelines, which determine the amount of the required materials. The third criterion is that ESP materials writers should leave some room for language teachers in order to incorporate their preferences into the prepared materials. According to Tomlinson (2011), the last important item, which should be considered in materials development, is the learning styles of the students.

\section{Methodology}

\subsection{Participants}

Sixty university students studying Electrical Engineering at the faculty of Engineering in Yazd University who had enrolled in the ESP course participated in this study. At the beginning of the second semester, the students were randomly divided into two groups, namely; control and experimental. The experimental group was taught based on the ESP approach while the control group was taught based on the traditional approach. 


\subsection{Instrumentations}

Two instruments were used in this study: 1) pretest posttest and 2) questionnaire. At the beginning of the second semester, all the students in the control and experimental groups were given a pretest in order to determine whether there was a significant difference in the reading, and knowledge of vocabulary and grammar of the students in the two groups. At the end of the semester, in the last session of the course, all the students were given a posttest in order to determine which one of the teaching approaches was more successful and whether there was a significant difference between the students of two groups in terms of their reading skills, and knowledge of vocabulary and grammar. It must be noted that the posttest had the same content as the pretest as there was a five-month interval between the two tests, which rendered memory effect negligible. In addition, a 20-item questionnaire was designed based on a 5-point Likert scale was the other instrument used in this study and administered to the students of the experimental group in order to explore their attitudes concerning team-teaching approach. The questionnaire was validated by one expert in Applied Linguistics and another in Electrical Engineering to follow Fulcher and Davidson's (2007) suggestions for questionnaire validation. Cronbach's coefficient alpha for the questionnaire was 0.90 , which demonstrates a high estimation of reliability. It is worth mentioning that the translated version of the questionnaire was given to the students in order to ensure their full understanding of all items.

\subsection{Procedures}

Both quantative and qualitative designs were utilized in the current study. Concerning the quantative aspect of the study, the design of this study was a quasi-experimental design with treatment, a pretest and a posttest, and nonrandom assignment of the participants. With regard to qualitative dimension, the questionnaire was used. Before the academic year (2014-2015) began, the content specialist and the language instructor discussed some items concerning the needs and lacks of the students. In addition, the content specialist introduced some materials relevant to Electrical Engineering. The sources included texts on various topics encompassing the characteristics of Electrical Engineering, the branches and sub-branches of Electrical Engineering, etc. Subsequently, the texts were selected based on various factors such as students' needs, students' field of study, the number of technical and semi-technical vocabulary items that the text covered, and the potential of the passages in introducing new grammatical structures. The general framework of the materials was established after selecting the texts. The final version of the newly developed materials was designed during the course of the experimental group based on the students' needs to follow the requirements of a learningcentered approach. The experimental group benefited from the presence of a content specialist together with a language instructor in class. The two instructors of the experimental group were in contact with each other during each week to discuss the details of the materials to be team-taught in each session. To avoid any possible conflicts between the language instructor and the content specialist, their responsibilities were clearly defined prior to each session. Moreover, the language instructor had close contact with the students in every session in order to explore their ideas and attitudes concerning the newly developed materials. It should be mentioned that among language skills, reading and, among language components, vocabulary and grammar were given more attention in the developed materials. However, the students in control group, similar to the common practice of any ESP course in Iran, were exposed to some pamphlets in which the content specialist read the texts, introduced technical vocabulary, and elaborated on the major ideas mentioned in the passage. Grammar translation was the prevailing method utilized in the control group.

\subsection{Data Collection Procedure}

At the beginning of the second semester, all the students in both groups were given a pretest in order to determine whether there was a significant difference in the reading skill, and the knowledge of vocabulary and grammar of the students in two groups. At the end of the semester, all the students were given a final exam which played the role of a posttest in order to determine whether there was a significant difference between the students of the two groups in terms of their reading skills and knowledge of vocabulary and grammar. Finally, at the end of the semester a questionnaire was administered to the students of the experimental group in order to elicit their perceptions regarding the newly developed materials.

\subsection{Data Analysis}

The collected data were processed and subjected to the statistical analysis using the SPSS software in order to communicate the obtained data and to answer the research questions. The descriptive statistics including mean (X) and percentages was obtained for the responses given to each item on the questionnaire. Two independent and two paired sample t-tests were conducted to determine whether there was any significant difference between the students in the experimental and the control group in terms of their reading skill, knowledge of vocabulary, and knowledge of grammar. The results of the data analysis are presented in the following section.

\section{Results}

An independent-samples t-test was conducted to examine the performances of the students in the experimental group and control group on the pretest. The result of data analysis revealed that there was no violation of the normality assumption according to one kolmogorov-smirnov test, presented in Tables 1 and Table 2, for control group sig=0.682 and for experimental group sig $=0.686$ which were well above 0.05 . 


\begin{tabular}{lll}
\hline \multirow{2}{*}{$\mathrm{N}$} & & Pre-test \\
\cline { 3 - 3 } Normal Parameters & & 30 \\
\hline Most Extreme Differences & Std. Deviation & 10.6333 \\
& Absolute & 3.90829 \\
\hline Kolmogorov-Smirnov Z & Positive & 0.131 \\
\hline Asymp. Sig. (2-tailed) & Negative & 0.131 \\
\hline
\end{tabular}

a. Test distribution is Normal.

Table 2. One-Sample Kolmogorov-Smirnov Test ${ }^{\mathrm{a}}$

\begin{tabular}{lll}
\hline & & Pre-test \\
\cline { 3 - 3 } $\mathrm{N}$ & & 30 \\
\hline Normal Parameters $^{\mathrm{a}}$ & Mean & 12.166 \\
& Std. Deviation & 2.983 \\
\hline Most Extreme Differences & Absolute & 0.131 \\
& Positive & 0.122 \\
& Negative & -0.131 \\
\hline Kolmogorov-Smirnov Z & & 0.715 \\
\hline Asymp. Sig. (2-tailed) & & 0.686 \\
\hline
\end{tabular}

a. Test distribution is Normal.

Looking at the Levene's test for Equality of Variances, presented in Table 3, it can be noticed that the p-value is more than 0.05 . If the $\mathrm{P}$ value is more than 0.05 , the homogeneity assumption is met.

Table 3. Independent Samples Test.

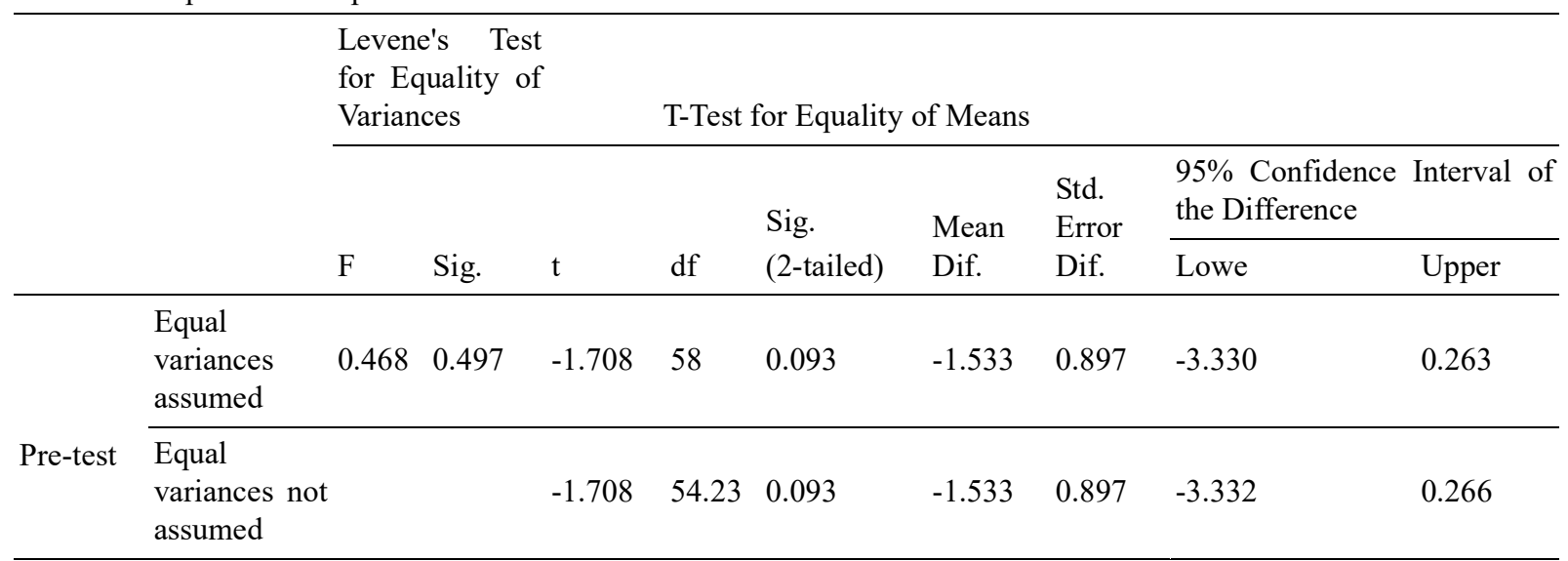

Referring to Tables 3 and Table 4, it can be seen that there was no significant difference between the students in control group $(\mathrm{M}=10.63, \mathrm{SD}=3.90)$ and experimental group $(\mathrm{M}=12.16, \mathrm{SD}=2.98)(\mathrm{t}=1.70, \mathrm{p}=.093, \mathrm{df}=58)$ in terms of their scores on the pre-test.

Table 4. Descriptive Statistics of Groups.

\begin{tabular}{llllll}
\hline & Group & $\mathrm{N}$ & Mean & Std. Deviation & Std. Error Mean \\
\hline Pre-test & Class 1-3 & 30 & 10.633 & 3.908 & 0.713 \\
\cline { 2 - 5 } & Class 3-5 & 30 & 12.166 & 2.983 & 0.544 \\
\hline
\end{tabular}

The second independent-samples t-test was conducted to examine the performance of the students in the experimental group and control group on the posttest. The analysis of data revealed that there was no violation of the normality assumption according to one kolmogorov-smirnov test, indicated in Tables 5 and Table 6 , for control group sig=0.78 and for experimental group sig $=0.83$ which were well above 0.05 . 


\begin{tabular}{lll}
\hline & & Pre-test \\
\cline { 3 - 3 } $\mathrm{N}$ & & 30 \\
\hline Normal Parameters $^{\mathrm{a}}$ & Mean & 13.433 \\
& Std. Deviation & 4.320 \\
\hline Most Extreme Differences & Absolute & 0.120 \\
& Positive & 0.120 \\
\hline Kolmogorov-Smirnov Z & Negative & -0.071 \\
\hline Asymp. Sig. (2-tailed) & & 0.657 \\
\hline a. Test distribution is Normal. & & 0.781 \\
c. Group = Class 1-3 & &
\end{tabular}

Table 6. One-Sample Kolmogorov-Smirnov Test ${ }^{\mathrm{c}}$.

\begin{tabular}{lll}
\hline \multirow{N}{*}{ Normal Parameters $^{\mathrm{a}}$} & & Pre-test \\
\cline { 3 - 3 } & & 30 \\
\hline Most Extreme Differences & Mean & 16.333 \\
& Std. Deviation & 4.011 \\
\hline Kolmogorov-Smirnov Z & Absolute & 0.114 \\
\hline Asymp. Sig. (2-tailed) & Positive & 0.097 \\
\hline
\end{tabular}

a. Test distribution is Normal.

c. Group = Class 3-5

Looking at the Levene's test for Equality of Variances, presented in Table 7, it can be noticed that the p-value is more than 0.05 . So that, the homogeneity assumption is met. As Tables 7 and Table 8 illustrate, there was a significant difference between the students in control group $(M=13.43, S D=4.32)$ and experimental group $(M=16.33, S D=4.01)(t$ $=2.69, \mathrm{p}=.009, \mathrm{df}=58)$. The result revealed that the students in the experimental group outperformed the students in the control group on the posttest.

Table 7. Independent Samples Test

\begin{tabular}{|c|c|c|c|c|c|c|c|c|c|c|}
\hline & & \multicolumn{9}{|c|}{$\begin{array}{l}\text { Levene's Test } \\
\text { for Equality of T-test for Equality of Means } \\
\text { Variances }\end{array}$} \\
\hline & & \multirow[t]{2}{*}{$\mathrm{F}$} & \multirow[t]{2}{*}{ Sig. } & \multirow[t]{2}{*}{$\mathrm{t}$} & \multirow[t]{2}{*}{$\mathrm{df}$} & \multirow[t]{2}{*}{$\begin{array}{l}\text { Sig. } \\
\text { (2-tailed) }\end{array}$} & \multirow[t]{2}{*}{$\begin{array}{l}\text { Mean } \\
\text { Difference }\end{array}$} & \multirow[t]{2}{*}{$\begin{array}{l}\text { Std. Error } \\
\text { Difference }\end{array}$} & \multicolumn{2}{|c|}{$\begin{array}{l}95 \% \text { Confidence } \\
\text { Interval of the } \\
\text { Difference }\end{array}$} \\
\hline & & & & & & & & & Lower & Upper \\
\hline \multirow{2}{*}{ Post-test } & $\begin{array}{l}\text { Equal variances } \\
\text { assumed }\end{array}$ & 0.25 & 0.615 & -2.69 & 58 & 0.009 & -2.900 & 1.076 & -5.054 & -0.745 \\
\hline & $\begin{array}{l}\text { Equal variances } \\
\text { not assumed }\end{array}$ & & & -2.69 & 57.6 & 0.009 & -2.900 & 1.076 & -5.054 & -0.745 \\
\hline
\end{tabular}

Table 8. Descriptive Statistics of Groups.

\begin{tabular}{llllll}
\hline & Group & N & Mean & Std. Deviation & Std. Error Mean \\
\hline \multirow{2}{*}{ Post-test } & Class 1-3 & 30 & 13.433 & 4.320 & 0.788 \\
& Class 3-5 & 30 & 16.333 & 4.011 & 0.732 \\
\hline
\end{tabular}


The difference on the pretest and posttest of the students in control group was computed using a paired-samples t-test. As Tables 9 and Table 10 illustrate, the results indicated a statistically significant increase in their scores from pretest $(\mathrm{M}=10.63, \mathrm{SD}=3.90)$ to post-test $(\mathrm{M}=13.43, \mathrm{SD}=4.32), \mathrm{t}(30)=2.26, \mathrm{p}<0.05$ (two-tailed). The eta-squared statistic (0.149) indicated a large effect size.

Table 9. Paired Samples Statistics.

\begin{tabular}{llllll}
\hline & & Mean & N & Std. Deviation & Std. Error Mean \\
\hline Pair 1 & Pre-test & 10.63 & 30 & 3.908 & 0.713 \\
\cline { 2 - 6 } & Post-test & 13.43 & 30 & 4.320 & 0.788 \\
\hline
\end{tabular}

Table 10. Paired Samples Test.

\begin{tabular}{|c|c|c|c|c|c|c|c|c|c|}
\hline & & \multicolumn{8}{|c|}{ Paired Differences } \\
\hline & & \multirow[t]{2}{*}{ Mean } & \multirow[t]{2}{*}{ Std. D } & \multirow[t]{2}{*}{$\begin{array}{l}\text { Std. } \\
\text { Error } \\
\text { Mean }\end{array}$} & $\begin{array}{l}95 \% \\
\text { Interval } \\
\text { Differen }\end{array}$ & $\begin{array}{l}\text { Confidence } \\
\text { of the } \\
\text { ice }\end{array}$ & \multirow[t]{2}{*}{$\mathrm{t}$} & \multirow[t]{2}{*}{$\mathrm{df}$} & \multirow[t]{2}{*}{$\begin{array}{l}\text { Sig. } \\
\text { (2-tailed) }\end{array}$} \\
\hline & & & & & Lower & Upper & & & \\
\hline Pair 1 & $\begin{array}{l}\text { Pre-test } \\
\text { Post-test }\end{array}$ & -2.8 & 6.75 & 1.234 & -5.323 & -0.276 & -2.269 & 29 & 29 \\
\hline
\end{tabular}

a. Group = Class 1-3

A dditionally, the difference in the pretest and posttest of the students in the experimental group was computed using a paired-samples t-test. As illustrated in Tables 11 and Table 12, the results indicated a statistically significant increase in their scores from pretest $(\mathrm{M}=12.16, \mathrm{SD}=2.98)$ to post-test $(\mathrm{M}=16.33, \mathrm{SD}=4.01), \mathrm{t}(30)=4.74, \mathrm{p}<0.05$ (two-tailed). The eta-squared statistic (0.43) indicated a large effect size. To sum up, it can be said that although the posttest scores of the students in both groups improved significantly in comparison to those of their pretest, the students in experimental group performed much better in their posttest than those in the control group.

Table 11. Paired Samples Statistics.

\begin{tabular}{llllll}
\hline & Mean & N & Std. Deviation & Std. Error Mean \\
\hline Pair 1 & Pre-test & 12.166 & 30 & 2.983 & 0.544 \\
\cline { 2 - 5 } & Post-test & 16.333 & 30 & 4.011 & 0.732 \\
\hline
\end{tabular}

Table 12. Paired Samples t Test

\begin{tabular}{|c|c|c|c|c|c|c|c|c|c|}
\hline & & \multicolumn{5}{|c|}{ Paired Differences } & & \multirow{3}{*}{$\mathrm{df}$} & \multirow{3}{*}{$\begin{array}{l}\text { Sig. } \\
\text { (2-tailed) }\end{array}$} \\
\hline & & \multirow[t]{2}{*}{ Mean } & \multirow[t]{2}{*}{ Std. D. } & \multirow[t]{2}{*}{$\begin{array}{l}\text { Std. Error } \\
\text { Mean }\end{array}$} & $\begin{array}{l}95 \% \\
\text { Interval } \\
\text { Differe }\end{array}$ & $\begin{array}{l}\text { Confidence } \\
\text { of the } t\end{array}$ & & & \\
\hline & & & & & Lower & Upper & & & \\
\hline Pair 1 & $\begin{array}{l}\text { Pre-test } \\
\text { Post-test }\end{array}$ & -4.166 & 4.814 & 0.878 & -5.964 & -2.368 & -4.740 & 29 & 0.000 \\
\hline
\end{tabular}

a. Group = Class 3-5

\subsection{Data Analysis}

It should be pointed out that the items on the questionnaire related to various categories namely; vocabulary, grammar, reading, speaking, writing, cooperation between the language and content instructors and students' satisfaction of teamteaching approach were put together and described as a group. The percentage of each option of the individual items was presented and explained. Questions 1, 4 and 14 concerning the students' opinions about the effect of team-teaching while learning vocabulary. Most of the students (80\%) agreed that the content instructor should teach technical vocabulary; however, some students $(20 \%)$ had no idea. More than half of the students $(56 \%)$ agreed with the teaching semi-technical vocabulary by the language instructor; on the contrary, $40 \%$ of the learners reported that they had no idea 
concerning the above mentioned statement. A considerable number of the students $(67.4 \%)$ agreed that instructions provided by the language instructor was helpful in increasing their knowledge of vocabulary; in contrast, only few students $(6.6 \%)$ disagreed regarding the above mentioned statement. Nearly half of the students $(40 \%)$ agreed that the language instructor should teach grammar; in contrast, less than one-third of the students $(20 \%)$ disagreed regarding the above mentioned statement. More than half of the students (53.3\%) agreed that the language teacher was helpful in increasing their knowledge of grammar; however, one-third of the students (30\%) had no idea.Questions 10, 11 and 17, which explored the students' opinions about the effect of team-teaching on their reading skill. With respect to students' answers to Q10, most of the students $(60 \%)$ agreed that team-teaching increased their reading ability; on the contrary, some students (16.7\%) disagreed regarding the above mentioned statement. In response to Q11, a good majority of the students $(70 \%)$ agreed that team-teaching reduced their reading comprehension difficulties; however, some students (23.3\%) had no idea concerning the above mentioned statement. In response to Q17, a majority of the students (76.7\%) agreed that the language instructor's instructions were helpful in increasing their reading ability; in contrast, few students (6.6\%) disagreed regarding the above mentioned statement. Q18 and Q19 of team-teaching questionnaire elicited students' opinions regarding the effect of team teaching on students' speaking ability. With respect to students' answers to Q18, a large number of students (70\%) agreed that the language instructor improved their pronunciation; in contrast, some students (13.3\%) disagreed regarding the above mentioned statement. In response to Q19, some students $(13.3 \%)$ agreed that the language instructor increased their speaking ability; however, half of the students $(50 \%)$ disagreed regarding the above mentioned statement. This is due to the fact that throughout the semester, the development of students' speaking skill was not emphasized. Question 16 was related to the effect of team teaching on students' writing ability. More than half of the students $(60 \%)$ disagreed that the language instructor increased their writing ability; however, some students $(13.3 \%)$ reported that the language teacher was helpful in increasing their writing ability. Question 12 explored the students' attitude towards the cooperation between the language teacher and the content specialist in the class. A large majority of the students $(70 \%)$ agreed that there was cooperation between the language teacher and content instructor in the class; however, one-third of the students $(30 \%)$ had no idea concerning the above mentioned statement. Most of the team-taught students (76.7\%) agreed that the language instructors' guidance helped them in doing the exercises of the books; in contrast, few students $(6.6 \%)$ disagreed regarding the above mentioned statement. A large number of the students $(66.7 \%)$ responded that team-teaching approach increased their motivation; however, some students $(13.3 \%)$ had no idea. More than half of the students $(56.7 \%)$ disagreed that content specialist teach subject-specific content alone; on the contrary, $20 \%$ of the students had no idea. A good majority of the students $(73.4 \%)$ agreed with team-teaching; however, some students $(13.3 \%)$ had no idea. Moreover, almost all of the students $(86.7 \%)$ agreed that team-teaching increased their success in ESAP course; in contrast, few students (3.3\%) disagreed regarding the above mentioned statement. A considerable number of the students (70\%) disagreed that teamteaching was boring; in contrast, some students (13.3\%) agreed regarding the above mentioned statement. A considerable number of the students (70\%) disagreed that team-teaching was confusing; however, some students (13.3\%) had no idea. A good majority of the students (83.3\%) disagreed that team-teaching disturbed their learning; however, some students $(16.7 \%)$ had no idea.

\section{Discussion}

A first aim of the present study was to explore students' attitudes towards team-teaching approach by administering a twenty-item questionnaire to the students at the end of the semester. This questionnaire included items regarding the effect of team-teaching approach in learning different aspects of language which should be given priority, and the content specialist and language instructor's proficiency in teaching different sections of the newly developed materials. In the present study, the content specialist taught the technical vocabulary and the language instructor taught the semitechnical vocabulary. A considerable number of students (67.8\%) agreed with the team-teaching phenomenon in learning new technical and semi-technical vocabulary. According to Dudly-Evans and St. John (1998), semi-technical vocabulary is used in general life contexts but has a higher frequency in scientific and academic descriptions and discussions. They asserted that ESP teachers should teach learners the semi-technical vocabulary, which has a higher frequency in a scientific field. As it has been echoed in the literature, it is not the job of the language teachers to teach technical vocabulary (Barber, 1962; Higgins, 1966; Cowan, 1974). Nearly two-third of the students (40\%) admitted that the language instructor should teach grammar and more than half of the students $(53.3 \%)$ reported that the language teacher increased their knowledge of grammar. One of the problems that prohibit students from understanding the reading texts is the lack of the threshold knowledge of grammar. Hutchinson and Waters (1987) support materials that cover a wide range of fields, arguing that the grammatical structures, functions, discourse structures, skills and strategies of different disciplines are identical. Most of the students $(68.9 \%)$ agreed that the team-teaching has positive effect on their reading skill. This finding confirms the results of Song's (1998) study who found that less proficient readers benefitted from the instructions provided by the instructor for developing students' reading strategies. According to Oxford and Celce-Murcia (2001, p. 5), "teaching reading skills to non-native speakers of English involves unique problems and challenges at all conceivable levels of instruction". Students clearly need help in learning to read in a foreign language. Unassisted, many students learn strategies that impede their obtaining meaning efficiently from printed text (Hosenfield, 1984). Moreover, the successful reading needs the activation of metacognitive reading strategies, that is, deciding important points, summarizing, making inferences, asking questions (Allen, 2003). Less than half of the students $(41.65 \%)$ agreed that the team teaching has positive effect on their speaking ability. One of the areas in which students have difficulty is pronunciation. The researcher as the language teacher responded to this problem by providing correct pronunciation of the words in the class and introducing phonetic symbols to the students to enable 
them to pronounce the words correctly without the teachers' help. The other area of difficulty for some of the students was that they were not able to detect different parts of speech; therefore, the language instructor attempted to introduce some of the English affixes; however, because time constraint did not allow devoting more time on this issue, he introduced some grammar books, which could help them. It is worth mentioning that the focus of this ESAP class was not on speaking or writing skills. More than half of the students $(60 \%)$ admitted that the language teacher's instructions were not helpful in increasing their writing ability. This is due to the fact that the focus of the course was on developing students' reading skills. Because of time constraint developing students' writing or speaking skill was not emphasized. A large majority of the students (70\%) revealed positive attitudes towards the cooperation between language teacher and content specialist in the class. Chang and $\mathrm{Wu}$ and $\mathrm{Ku}(2005$, p. 774) notes that thorough interaction the barrier between content and language instructor may be removed gradually. It seems that through continuous cooperation and collaboration between the two teachers, the advantages of this interaction will be appreciated. Almost all students $(76.7 \%)$ indicated that the language teacher's guidance helped them in doing the exercises of the book. Similarly, a large number of students $(66.7 \%)$ reported that team-teaching approach increased their motivation. Moreover, more than half of the students $(56.7 \%)$ admitted that content specialist could not teach subject-specific content alone. A good majority of the students $(73.4 \%)$ were satisfied with the team-teaching approach. With respect to the students' ideas about the effect of team-teaching on their success in ESAP course, almost all the students $(86.7 \%)$ reported that this approach paved the way for their academic success Additionally, a good majority of the students (70\%) responded that teamteaching was not boring or confusing. Similarly, a considerable number of students $(68.77 \%)$ indicated that teamteaching did not disturb their learning. Anderson (1991) reached a conclusion that in well-controlled studies both teachers and students have been shown to prosper. He suggests that team-teaching approach exposes the students to multiple perspectives because they receive different perspectives from two experts. Most of the team-taught students who participated in the present study reported positively regarding the efficiency of team teaching approach. The second research question investigated the extent to which the newly developed materials were effective in enhancing students' English proficiency in an ESAP program. A pre-test was administered to the students at the beginning of the semester which served two purposes; first, as an indicator that both groups were at the same level of English proficiency at the beginning of the semester; second, it was used as the post-test to assess students' English proficiency at the end of the semester. The results revealed that at the beginning of the semester, there was no significant difference between students in both groups that is, the control and experimental groups in terms of their English proficiency; since the analysis of data on the pre-test, indicates that the mean of score of the students in experimental and control group was 10.63 and 12.16, respectively. However, the results of the post-test revealed that although the scores of the students in both experimental and control group improved significantly in comparison to their performance on the pre-test, there was a significant difference between the students of experimental group and those of control group in terms of their proficiency in English at the end of the semester, i.e. the post-test mean score of the students who were taught the newly developed materials (16.33) was much greater than that of those who were exposed to traditional approach (13.43). This implies that Electrical Engineering students who were taught through team teaching approach performed better than those taught by a single instructor. These findings of the present study are in line with some previous research about the effect of team-teaching on English proficiency of the learners (Carrell, Pharis \& Liberto 1989; Akyel \& Salataci, 2002; Song, 1998). The results are also in harmony with those gained by Carrell, Pharis and Liberto (1989) who examined the effect of the instruction of cognitive and meta-cognitive strategies to the students on their reading comprehension in the L2 context; they reported that the combined effects of meta-cognitive and cognitive strategies enhanced the students' reading comprehension. The results of this research are also in the same line with some studies conducted in Iran (Barati, 1992, Sedighi, 1998). In all these studies, it was revealed that the instruction of reading strategies improves reading ability of the learners. The results of the present study support the findings of Jackson and Davis (2000) as well as Roffier (2002) that team teaching creates high professional growth. The superiority of team teaching over traditional approach has confirmed findings of Whitefield (2000) and Washington (2001) who reported that there had been significant improvement in the English achievement of the team-taught students by a group of teachers over that of those in the traditional single teacher approach.

\section{Conclusion}

As mentioned earlier, this study was designed in order to investigate the students' attitudes and beliefs concerning the team-teaching approach. In addition, this study tried to explore the extent to which the newly developed materials were effective in terms of enhancing Electrical Engineering students' English achievement in an ESAP program. The results of the present study revealed that majority of the students were satisfied with the newly designed course book. As Jordan (1997) points out that, students become motivated if they find a relationship between the materials content and their needs. Therefore, it can be asserted that the ESP materials can be effective when it is designed according to learners' needs and objectives. Furthermore, there had been significant improvement in the English proficiency of the students who were team-taught in comparison to those who were exposed to the traditional independent teaching. To sum up, the present study reports the importance of designing course book for ESAP students based on students' immediate and delayed needs as well as the necessity of cooperation and collaboration between language instructor and content specialist in all stages of planning, materials designing, teaching and evaluation. 


\section{References}

Akyel, A., \& Salatac1, R. (2002). Possible effects of strategy instruction on L1 and L2 reading. Reading in a Foreign Language, 14, 10-15.

Allen, S. (2003). An Analytic Comparison of three models of reading strategy instruction. International Review of Applied Linguistics, 41, 319-338.

Anderson, N. J. (1991). Individual differences in strategy use in second language reading and testing. The Modern Language Journal, 75, 460-472.

Atai, M. R. (2000). ESP revisited: a reappraisal study of discipline-based EAP programs in Iran. Esfahan University publication, Esfahan, Iran.

Barati, H. (1992). The effect of reading strategies on recall and retention. Unpublished Masteral thesis, Tarbiat Modares University, Tehran.

Barber, C. L. (1962). Some measurable characteristics of modern scientific prose. Contributions to English syntax and philology, 2, 21-43.

Bernard, R. \& Zemach, D. (2003). Materials for specific purpose. In: Tomlinson, B. (Ed.). Developing materials for language teaching. London: Continuum.

Carrell, P. L., Pharis, B. G., \& Liberto, J. C. (1989). Metacognitive strategy training for ESL reading. Tesol Quarterly, 20, 647-678.

Carrell, P., Pharis, B., \& Liberto, J. (1989). Metacognitive strategy training for ESL reading. TESOL Quarterly, 20, 463494.

Chang, Y. J., Wu, C. T., \& Ku, H. Y. (2005). The introduction of electronic portfolios to teach and assess English as a foreign language in Taiwan. TechTrends, 49, 30-35.

Dudley-Evans, T. \& St. John, M. J. (1998). Developments in English for specific purposes: A multi-disciplinary approach. Cambridge, UK: Cambridge University Press.

Ewer, J. R. and Lattore, G. (1969). A course in basic scientific English. London, Longman.

Field, M. L. (2006). Finding a path to fluent academic and workplace reading. Current trends in the development and teaching of the four language skills, 29, 329-354.

Flowerdew, J. (1992). Definitions in science lectures. Applied Linguistics, 13, 202-221.

Fulcher, G. \& Davidson, F. (2007). Language testing and assessment. London and New York: Routledge.

Grabe, W., \& Stoller, F. L. (2002). Teaching and researching reading. Harlow: Longman.

Higgins, J. J. (1966). Hard Facts Notes on Teaching English to Science Students. ELT Journal, 21, 55-60.

Hosenfeld, C. (1984). Case studies of ninth grade readers. Reading in a foreign language, 4, 231-249.

Hutchinson, T. \& Waters, A. (1987). English for Specific Purposes: A learning-centered approach. Cambridge: Cambridge University Press.

Jackson, W. \& Davis, G. A. (2000). Turning Point 2000: Educating adolescents in the 21st century. New York: Teachers College Press.

Jordan, R. (1997). English for Academic Purposes: A guide and resource book for teachers. Cambridge: Cambridge University Press.

Long, M. L. (2005). Second language needs analysis. Cambridge: Cambridge University Press.

Oxford, R. L., \& Celce-Murcia, D. M. (2001). Teaching English as a second or foreign language. Language Learning Styles and Strategies, 4, 359-366.

Riazi, A. (2005). Features of Quality EAP Textbooks: Insights from Literature and Book Reviews, In Kiani \& Khayamdar (Eds.) Proceedings of the First National ESP/EAP Conference, Vol. 1, Tehran, SAMT Publication.

Richards, J. C., Schmidt, R.( 2010). Longman Dictionary of Language Teaching and Applied Linguistics (4th Edition). London: Longman.

Sedighi, A. (1998). The effects of training in the use of reading strategies on the improvement of reading comprehension. Unpublished Doctoral dissertation, AllamehTabatabaei University, Tehran.

Sidorova, N. A. (2015). Features and teacher's role at educating English for specific purposes. In the World of Scientific Discoveries/V Mire Nauchnykh Otkrytiy, 63.

Song, M. J. (1998). Teaching reading strategies in an ongoing EFL university reading classroom. Asian Journal of English Language Teaching, 8, 41-54.

Tomlinson, B. (Ed.). (2011). Developing materials for language teaching, (pp. 479-489). London: Cromwell Press.

Washington, S. G. (2001). The effects of interdisciplinary teaming on middle school climate and school achievement. Dissertation Abstracts International, 61(09),3523.

Whitfield, T. J. (2000). Academic effectiveness of middle school instructional sup-port teams in Pennsylvania. Dissertation Abstracts International, 61(03), 871-872. 